\title{
The Origin, Archaeobotany and Ethnobotany of Sweet Chestnut (Castanea sativa Miller) in the Czech Republic
}

\author{
Jitka Kosňovskáa* \\ ${ }^{a}$ Laboratory of Archaeobotany and Palaeoecology, Faculty of Science, University of South Bohemia, Branišovská 31, 370 05 České Budějovice, Czech Republic
}

\section{ARTICLE INFO}

\section{Article history:}

Received: 16. September 2013

Accepted: 17. December 2013

\section{Key words:}

Castanea sativa

sweet chestnut

cultivation

ethnobotany

macroremains

Early Modern period

Prague Castle

\begin{abstract}
$A B S T R A C T$
This contribution deals with ethnobotanical knowledge and archaeobotanical findings of the sweet chestnut (Castanea sativa) in the Czech Republic. The appearance of Castanea sativa depended on the last glaciation and consequently approximately six areas as refugia are known up to present in Europe. Later distribution was primarily connected with human activities particularly during the Roman age. Archaeobotanical evidence during the Late Medieval period is rare in Central Europe and Early Modern evidence is exceptional. Despite the fact that this period has opened up new kind of relationships between humankind and plants, archaeobotanical analyses of materials dated to this period are still fairly rare. The unique collection of macroremains enriching our knowledge of the diet standard of high society, originating from the waste vault infill in Prague Castle, supports the importance of the use of sweet chestnuts at the beginning of the $17^{\text {th }}$ century. Based on recent archaeobotanical and historical data, chestnuts were not known in the Czech Republic earlier than the $16^{\text {th }}$ century when the first experimental planting began. This paper has given special attention to those first planting referred to as "kaštánky" in the scope of the ethnobotanical survey. In addition, the valuable multiple utilisation placed Castanea sativa among the most important useful plants.
\end{abstract}

\section{Introduction}

The Early Modern period represents an era when relationships between humankind and plants were broadly changing (Cotton 1996, 15). Despite the fact that archaeobotanical knowledge of the Modern Times still remains rare, it has had a significant impact on the ethnobotanical field. Archaeobotanical records, a rapid increase in imported plant products and the presence of neophytes is clearly visible in a number of archaeobotanical studies in the Czech Republic as well as in many historical studies dealing with trade and international movement of plants (Kočár et al. 2007; Beneš et al. 2012). Castanea sativa Mill. is among the most important tree species that has clearly appeared in archaeobotanical collections from the $16^{\text {th }}$ century (Beneš et al. 2012).

The range and scope of chestnut utilization in Europe at present can be traced as a staple food, charcoal, woodworks as well as a medicine for the prestigious candy marrón

*Corresponding author. E-mail: jitullka@gmail.com glacé or as a flavour of beer in France and Switzerland in particular. This paper deals with an archaeobotanical and ethnobotanical survey of Castanea sativa as one of the most important useful plants in the Mediterranean space summarizing the knowledge concerning its macro-remain finds throughout Europe with a special emphasis on the historical Czech Lands.

\subsection{Botanical overview}

Genus chestnut (Castanea) is a broadleaf tree species widespread in the Boreal Hemisphere related to the beech family (Fagaceae). There are 14 species over Asia, America and Europe (Table 1). European Castanea latifolia became extinct during the last Wiechselian glaciation, consequently sweet chestnut (Castanea sativa) is now the only native species in the Mediterranean and southern Central European regions (Bounous, Marinoni 2005), where the vegetation season lasts 160-180 days per year and freezing temperatures are not lower than $-27^{\circ} \mathrm{C}$ (Hejný, Slavík 2003).

Sweet chestnut (Castanea sativa Mill.) is a majestic tree 20-40 metres in height growing primarily in well watered acidophilic soils and at times exceeding 400 years of age. 
Table 1. Species of the genus Castanea according to Bounous and Marinoni (2005).

\begin{tabular}{|c|c|c|}
\hline Asia: & America: & Europe: \\
\hline -C. crenata Seib\&Zucc. & -C. dentata (Marsh.) Borkh. & -C. sativa Mill. \\
\hline -C. mollissima Blume & - C. pumila (L.) Mill. var. pumila & -C. latifolia Sord. \\
\hline -C. seguinii Dode & -C. pumila (L.) Mill. var. ozarkensis & \\
\hline -C. davidii Dode & -C. floridana Ashe (Sarg.) & \\
\hline \multirow[t]{3}{*}{ •C. henryi (Skan) Rehd.\&E.H.Wils. } & - C. ashei (Sudw.) Ashe & \\
\hline & -C. alnifolia Nutt. & \\
\hline & -C. paucispina Ashe & \\
\hline
\end{tabular}

The bark has a retiform pattern with deep furrows. The leaves are long and serrated, monoecious flowers grow in the long upright aments (catkins). The female flowers develop into nuts protected by thorny cupules. Based on the cultivar kind, cupules bear 1-3 nuts when ripe and open in two or four valves. The nuts have a smooth and coriaceous epicarp, which can be light brown or deep brown in colour with more or less evident stripes (Hejný, Slavík 2003; Koblížek 2006, 551; Větvička 1999, 216; Bounous et al. 2005). To enhance the harvest, they should be cultivated on north facing slopes where the blossoms are protected from early spring frost damage.

\subsection{Origin, history and current chestnut distribution in Europe}

The presence and spreading of sweet chestnut (Castanea sativa) depended on its ability to survive during the main glacial periods. The management of the developing human settlements may also affect the chestnut's natural regions. Based on radiocarbon-dated pollen records, anthropological and macrofossils records, six/seven regions as the Quaternary refugia of Castanea sativa were delimited (Figure 1): the Transcaucasia region, north-western Anatolia, the Apennine range in Emilia-Romagna (northern Italy), Colli Euganei and Monti Berici in Veneto (north-eastern Italy), the region around Lago di Monticchio on Monticchio on Monte Vulture (southern Italy), the Cantabrian coast on the Iberian Peninsula and in all probability also the Greek Peninsula (Peloponnese and Thessaly) and north-east Italy (Colli Euganei, Monti Berici in Veneto) (Conedera at al. 2004). Another possible refugium is suggested on the foothills of Vesuvius (Pasquale et al. 2010). Castanea sativa could have expanded elsewhere from these regions and there is no doubt the human cultures were also supportive (Conedera et al. 2004; Mercuri et al. 2013; Lauteri et al. 2004).

The first unambiguous evidence of chestnut cultivation is reported in palynological data of several regions in Anatolia, north-east Greece and south-east Bulgaria and dates back to approximately 3700 BP (2100-2050 cal. BC); (Zeit, Bottema 1991). In the later Middle Ages ( $11^{\text {th }}$ to $16^{\text {th }}$ centuries $)$ chestnut became an essential source of food and timber in the Mediterranean and the southern parts of Central Europe. As of the $13^{\text {th }}$ century it had also been registered in Hanseatic towns (Alsleben 2007). This medieval golden age of the chestnut declined progressively, however, due to climatic cooling (the Little Ice Age), the introduction of alternative crops from abroad such as maize and potatoes and also the Industrial Revolution which brought about higher usage of chestnut trees for charcoal (Conedera, Krebs 2008).

In various European regions, particularly in highlands and places without wheat production, chestnut cultivation

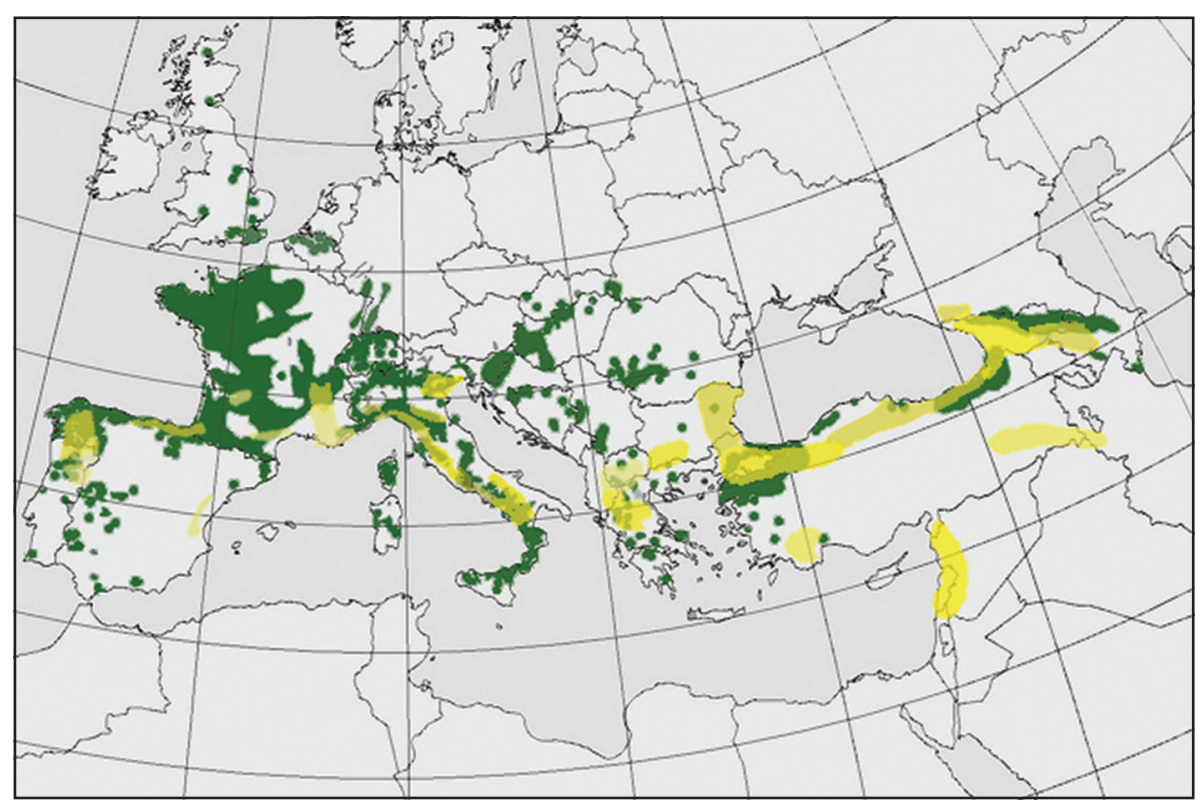

Figure 1. Present distribution of Castanea sativa (2009) in green. EUFORGEN distribution map, available from: http:// www.euforgen.org/distribution maps.html. Potential glacial refugia according Krebs et al. 2004 in yellow. 
became so predominant, so indispensable for the survival of the mountain population and the traditions, the lives and habits of these communities were so closely related to chestnuts that we can even talk of a "chestnut civilization" (Gabrielli 1994; Conedera et al. 2004). Chestnuts are common all over southern Europe, particularly in Italy, Corsica, France and Spain. Preferences in park planting, traditional orchard conservation, a warmer climate change and the high adaptive abilities of the chestnut influenced the expansion of its range where it occurs spontaneously. At present the most north-eastern site of the spontaneous spread of chestnut occurrence is in all probability situated in the town of Leba close to the outlet of the Leba River to the Baltic Sea (Urbisz, Urbisz 2007).

Figure 2. Nasavrky orchard, one of the 97 majestic trees.

\subsection{The history and current situation for Castanea sativa in the Czech Republic}

In the Czech flora sweet chestnut (Castanea sativa Mill.) is treated as a casual neophyte alien plant (Pyšek et al. 2002) distributed throughout the Czech Republic. Despite being an introduced species it is described in the first Czech herbarium written by Křišt’an z Prachatic in 1400-1403 (Čížek 1994). At present there are approximately 320 localities of chestnut in Czech Republic mainly in parks, gardens, urban vegetation as well as in forest stands and two orchards (Haltofová et al. 2005). Chestnut trees occur generally up to an altitude of $500 \mathrm{~m}$ with one exception, this being the topmost locality at an altitude of $678 \mathrm{~m}$ named Nejdek in Karlovy Vary (Haltofová, Jankovský 2003).

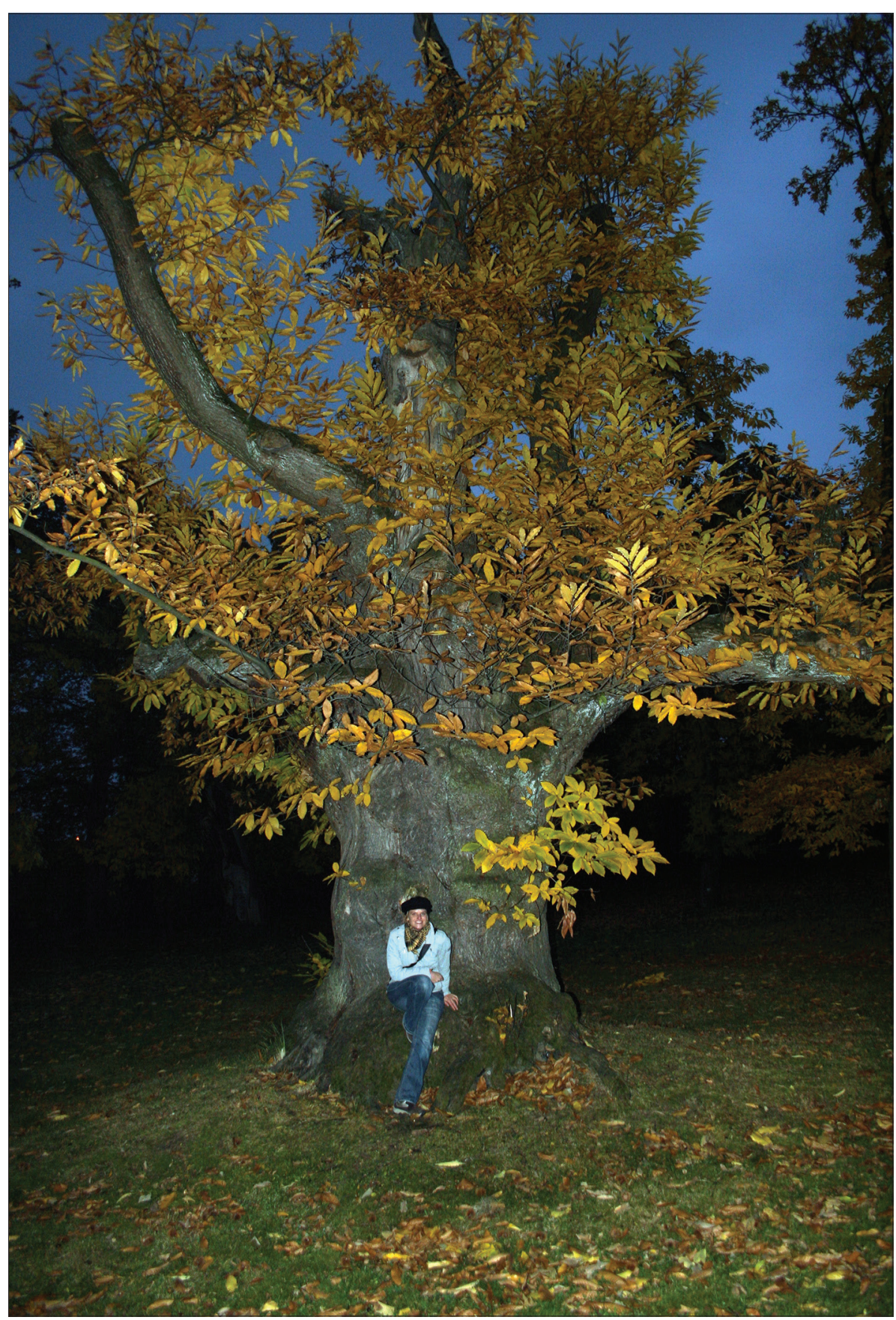


The first, most famous and oldest chestnut orchard is at Kamencove jezero lake near Chomutov and is mentioned in Bohuslav Balbín's Miscellanea historica regni Bohemiae from 1679. It can thereby be assumed that the first plantings came about in the $16^{\text {th }}$ century (Svoboda 1978). Chestnut came to Chomutov with the Jesuits from Italy, Spain and France who were summoned by Jiří Popel z Lobkovic in 1590 (Kokeš 1958). At present, the orchard is on a 2 ha area and consists of 133 trees which are listed as of 1976 as protected trees in the database of The Agency for Nature Conservation and Landscape Protection of the Czech Republic. The second most famous chestnut orchard is situated in Nasavrky (Chrudim). It was grown in 1776-1778 by Prince Adam Auersperg who brought six seedlings from Italy (Kokeš 1950; Pacáková-Hoštálková et al. 2004, 243). The current orchard is on 1.08 ha area and the oldest specimen named "Kněžák" came from the original planting (Haltofová; Jankovský 2003). The orchard was listed as a protected natural monument in 1991 and is part of the protected area Železné hory (Kos, Maršáková 1997). All together 97 specimens are present here (Figure 2).

The chestnut was considered a highly productive economic tree at the beginning of the $19^{\text {th }}$ century. It helped restore and increase income from overexploited forest in the Lovosice region in north-west Bohemia. The combination of chestnut brought advantages as the rapid growth of valued wood, trunk sprouting and quick fruit production also offered effective forest management with sheep grazing. Seedling fruit was donated from the Chomutov area where a celebrated chestnut trade was running and from the Lobkovic garden in Prague (Nožička 1953). Despite the fact that this project was not implemented over the entire area there are a number of recent chestnut localities which in all probability originate from this project, this being, for example, the chestnut stand Vinička in Březno or the parkland in Milešov (Haltofová 2001-2005).

The current distribution of sweet chestnut is close to the limit of its ecological optimum. In spite of this fact, chestnut can be considered a productive species both in terms of fruit-bearing as well as wood-producing. Chestnut could consequently be one of the species which could stabilize the existing oak and beech stands under conditions of climatic changes. An important element is the similar mycoflora of the roots of chestnut, oak and beech (Haltofová, Jankovský 2003).

\subsection{The etymology of the names sweet chestnut and Castanea sativa}

Chestnuts have been cultivated for nuts and wood for thousands of years. The Latin name Castanea is believed to have come from the Greek Kastanea, a city in Pontus (Anagnostakis 2009). A beautiful legend is also linked with the Latin name. Caste Nea (Chaste Néa) was a beautiful nymph of the goddess Diana who Jupiter desired to be with. She rather chose to lose her life rather than her virtue. The furious Jupiter changed her into a chestnut tree with the thorny burs standing as a reminder of her painful destiny.
The English word chestnut (Middle English chasten nut or chasteine) is derived from the French châtaigne (Bounous, Marinoni 2005). The name in Old English cysten may be related to the old Czech language word kystin stated in the Czech Krrišt'an's herbarium from the early $15^{\text {th }}$ century. The Czech name kaštan is undoubtedly derived from the Latin castanea (Jungmann 1836, 976; Kott 1878, 1097).

\section{Material and Methods}

\subsection{Compilation of archaeobotanical macro-remain evidence}

The list of archaeobotanical records was compiled from H. Kroll's species database "Literature on the archaeological remains of cultivated plants 1981-2004" supplemented with later studies and a complete list of sweet chestnut finds in the Czech Republic. It was necessary to point out the possible missing studies or local reports published only in regional journals or unpublished sources.

\subsection{The archaeological context of the chestnut finds in the Czech Republic}

Efforts to collect all the archaeological sites in the Czech Republic with the Castanea sativa appearance were carried out through the study of local literature and via contacts with authors of macro-remains analysis. Altogether, four archaeological sites were found. Three of them are archaeological sites in Prague, dating from the $16^{\text {th }}$ to the $18^{\text {th }}$ centuries, while the last one is from Klatovy dating to the interval from the $15^{\text {th }}$ to the $17^{\text {th }}$ centuries.

This paper also presents part of the author's archaeobotanical survey which took place in Prague Castle, Vladislav Hall, one of the most prominent archaeological sites in the Czech Republic. During the wooden floor renovation in the Late Gothic Vladislav Hall, an archaeological excavation was carried out in 2008/2009. The mixture of organic material, which has an insulation function of waste vault infill preserved in a perfect dry condition, was separated by traditional archaeobotanical methods (dry sieving, flotation, hand-picking). The numerous collections primarily of imported botanical species - sweet chestnut included demonstrated the high social status of Prague Castle at the end of the $16^{\text {th }}$ and $17^{\text {th }}$ centuries (Beneš et al. 2012). The finding of 93 sweet chestnuts shell fragments represents only a few archaeobotanical records of the total in the Czech Republic.

\subsection{Investigation of the sweet chestnut ethnobotanical context}

The ethnobotanical survey is based on the author's own field study in the most renowned Czech and Slovak localities in relation to historical and current literature. Information on Castanea sativa management in orchards, local habits and traditional use of chestnuts was gathered through interviews with the grounds managers or orchard owners and colleagues. The study was also aimed at photography documentation and fruit collection throughout the visited 
locality for culinary experiments such as marron glacé. Fruit was also planted in the hedgerow and successfully germinated for future experiments with abundant stems for weaving of baskets and mats. A special emphasis was put on collecting various information and data about the historical spread, utilisation and current situation of Castanea sativa in the Czech Republic. Archaeobotanical data, knowledge of older literature and investigation of historical resources were used for these results in order to summarize miscellaneous utilisation of Castanea sativa in general.

\section{Results and discussion}

\subsection{Compilation of Castanea sativa archaeobotanical records}

There are 23 archaeobotanical studies in H. Kroll's species database "Literature on the archaeological remains of cultivated plants 1981-2004". These data were supplemented by 7 European studies and 4 studies from the Czech Republic. In summary, the archaeobotanical compilation contains 34 studies dealing with Castanea sativa macroremain finds (Table 2). All the studies deal with the time interval from the Roman Period up to the $18^{\text {th }}$ century. The majority of the studies are located not surprisingly in Italy and France in light of the fact that Castanea sativa was an autochthonous occurrence there. The presence of Castanea sativa macro-remains, outside the native area such as in the Czech Republic is quite interesting and worthy of a detailed observation.

\subsection{Castanea sativa in the archaeobotanical and historical records in the Czech Republic}

Chestnut macro-remains were only detected at four Czech archaeological sites (Figure 3), all dating back not earlier than the $15^{\text {th }}$ century. The first and the most numerous finds came from the waste vault infill of Vladislav Hall in Prague Castle in terms of the number of 93 nuts with the fragments dating to the end of the $16^{\text {th }}$ and $17^{\text {th }}$ centuries (Benes et al. 2012). The perfectly dry conditions of the waste infill provided excellent preservation of the chestnut peel even including tomentum (Figure 4). These numerous finds present Prague Castle as a prestigious place with plentiful goods in supply. Another two localities are again from Prague and were detected in cesspits dating to the $17^{\text {th }}-18^{\text {th }}$ centuries. The first case is recorded from material in a cesspit on Melantrichova Street 465-I with a total number of 23 nuts and fragments (Kočár et al. 2007), while the second evidence has been taken from a cesspit in the Capuchin Monastery on Náměstí republiky Square with a total number of 8 nuts and fragments (Kočár et al. 2009). The findings in the Prague historical core are not surprising because of its European trade centre status. The fourth archaeological context with sweet chestnut, dating to the time span $15^{\text {th }}-17^{\text {th }}$ centuries, is recorded from a well infill detected during an excavation in the Jesuit church in the town of Klatovy (Kamenická 1990, 836). Chestnuts (unfortunately in an unknown number of nuts and fragments) were found in a well infill which was located in the basement of the Korálkovský house which burnt down on $12^{\text {th }}$ May 1579 (Kamenická, pers. com.). The well infill was dated by ceramic fragments to the end of the $15^{\text {th }}$ and to the

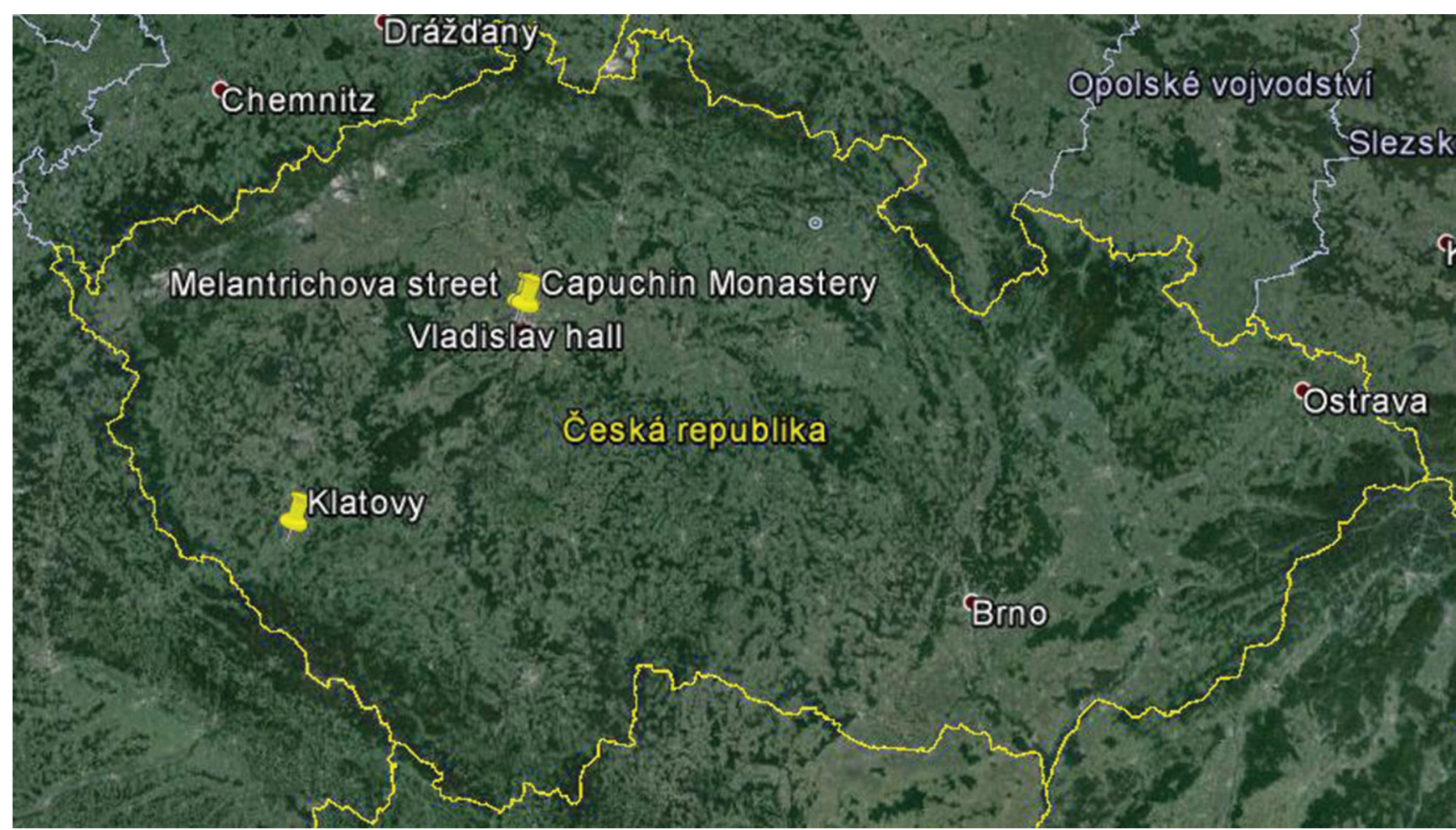

Figure 3. Map of four archaeological sites in the Czech Republic, where chestnut macro-remains were detected. 


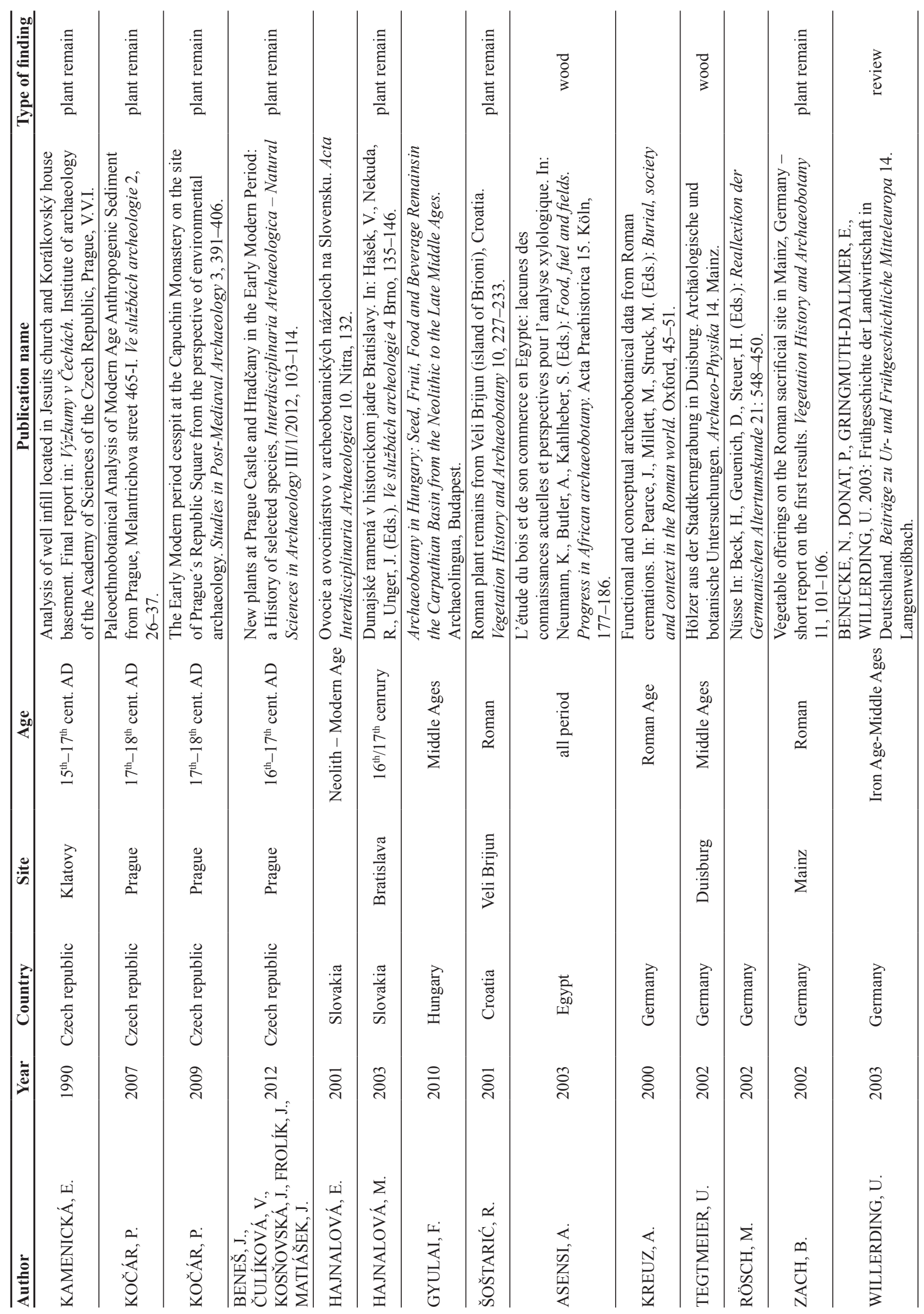




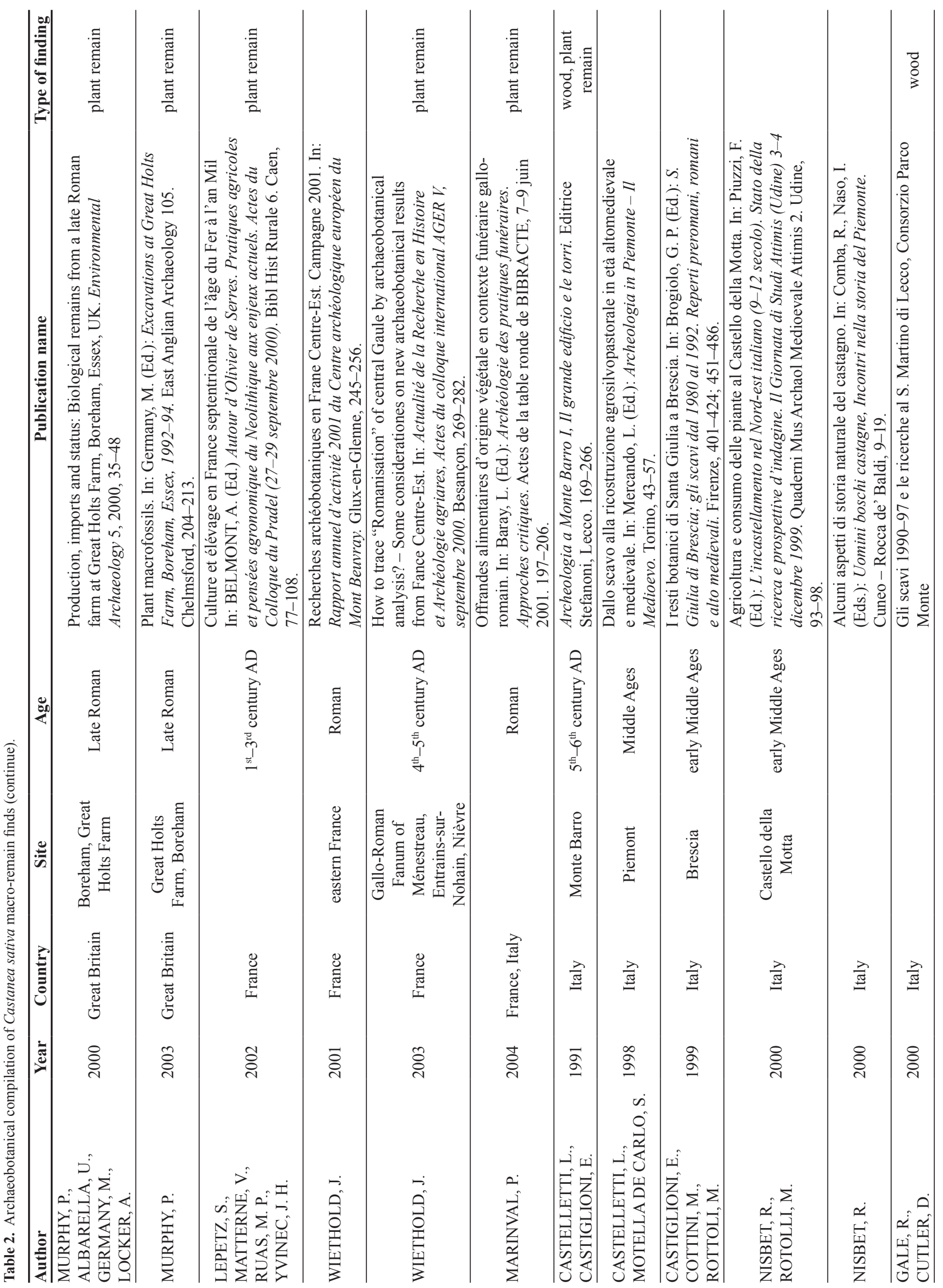




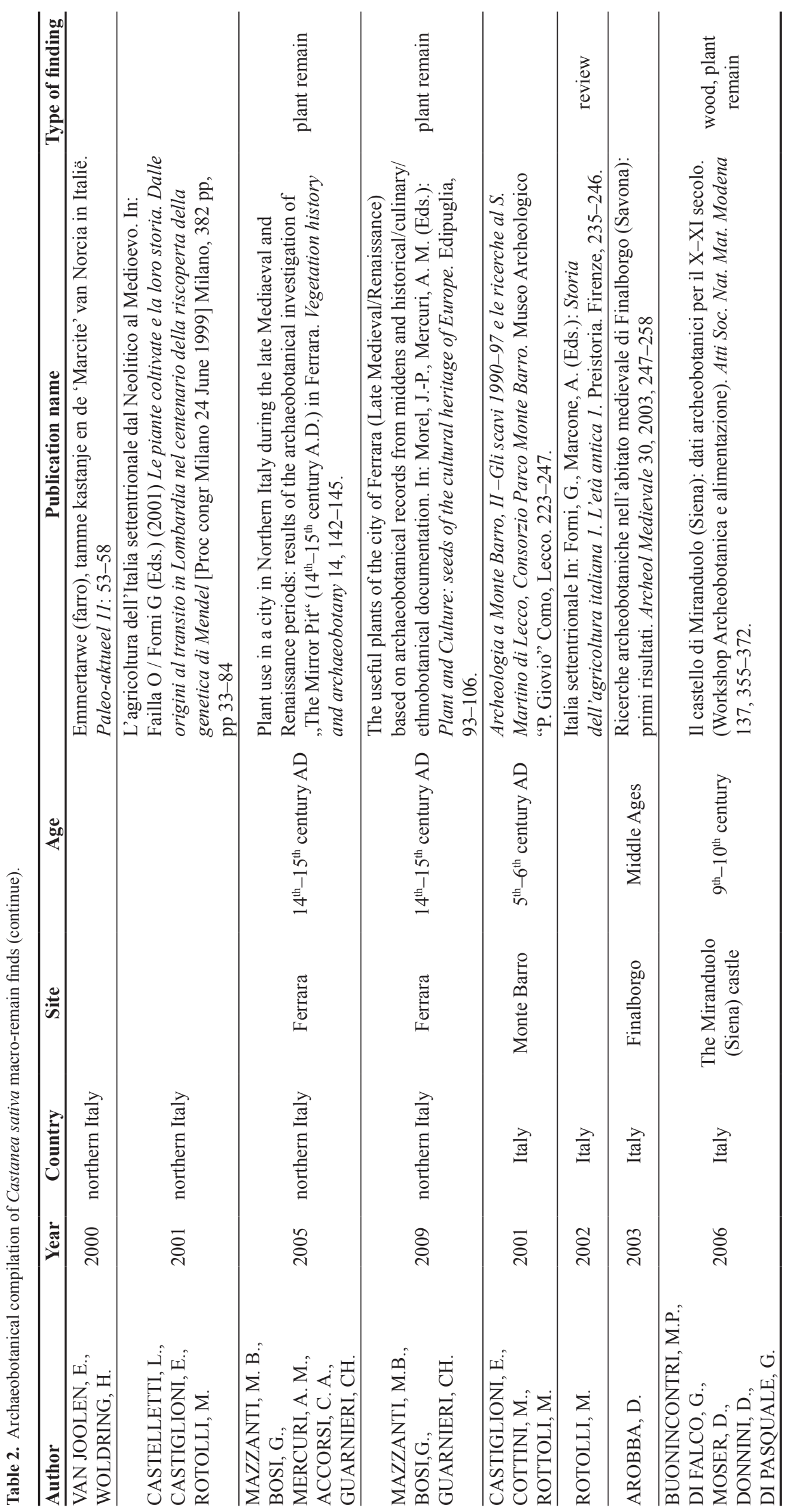


Figure 4. Achenes fragments found in waste vault infill of Vladislav hall in Prague castle dated to the end of the $16^{\text {th }}$ and $17^{\text {th }}$ century.

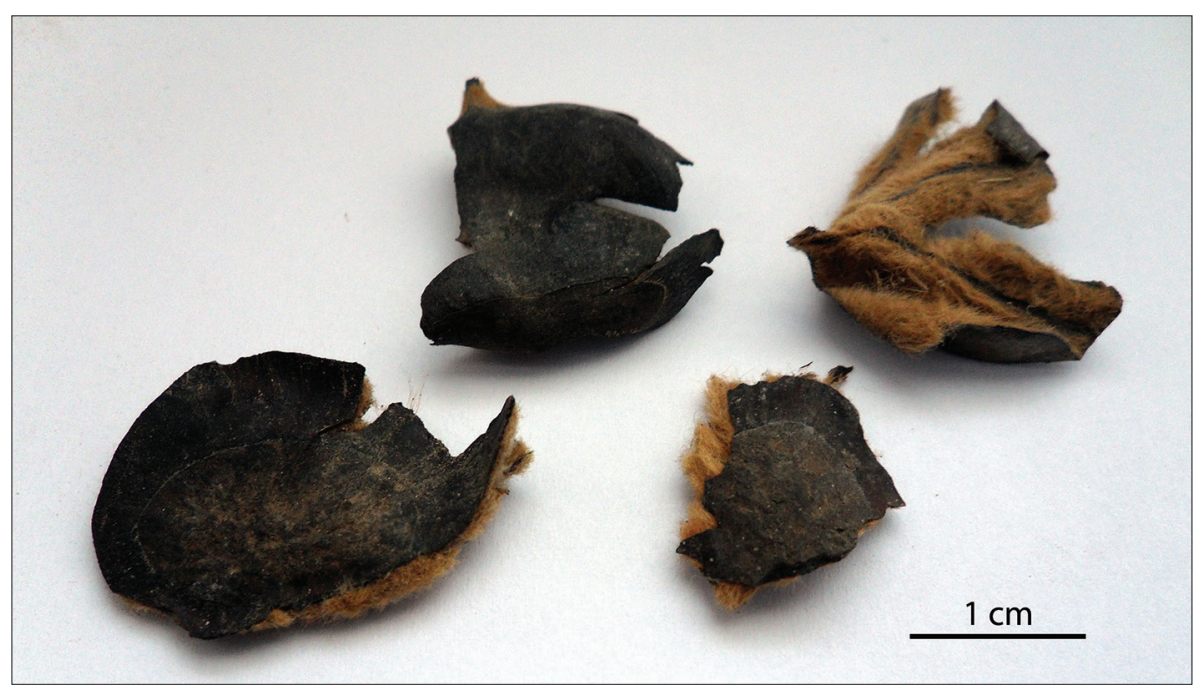

first half of the $16^{\text {th }}$ century (Vondráčková 1996) thus these findings could represent the oldest known archaeobotanical evidence of chestnuts represented as fruit in the Czech Republic. Historical sources from the $15^{\text {th }}$ century refer to the fact that the town of Klatovy had sophisticated crossborder trade competing with Prague (Sýkorová 2010, 82) which explains the chestnut presence outside Prague as the predominant trade centre.

Chestnuts remain, however, a rare taxon in archaeobotanical samples and better known from historical sources. It is known, for example, from the expense accounts of Czech aristocratic seats as a common fruit commodity since the $16^{\text {th }}$ century (Hrdlička 2000, 61). Local and world trade was particularly concentrated in Prague which was the centre of the economic and political life for all of Central Europe in the Early Modern period. Chestnuts were primarily imported from Italy or from the Tyrol. Local production can also not be excluded (Kokeš 1958) as confirmed in a Prague fruit market establishment from as far back as 1456 related to local orchardists (Winter 1906, 931). Chestnut availability

in Prague marketplaces is confirmed by another expense account from 1650 when a festive banquet was prepared in Rakovník for a visit by vice-chamberlain Oldřich Sezima (Winter 1892, 148).

The next example comes from Prince Ferdinand, of the Schwarzenberg family, who had a grocery list prepared by a Viennese businessman where chestnuts were included in $1689^{1}$. Jaromerrice castle and the adjoining garden were built in the 1720s. At this time correspondence between the governor of the castle Jan Josef Stampa and Count Jan Adam from Questenberk revealed efforts to plant sweet chestnut as well. They even built greenhouses due to problematic outdoor growing ${ }^{2}$. Chestnut consumption is nevertheless documented

${ }^{1}$ State Regional Archives Třeboň, department Český Krumlov, Schwarzenberk's Family archive, Patrial inventory for department Familia primogenitura, Dienerschäft, sign. F.P.h - 59, 1689.

${ }^{2}$ Letters to Governor Stampa from Jan Adam of Questenberk on $11^{\text {th }}$ March 1723, stored in the Moravian Provincial Archives Brno, Kounic's Family archive, inv. n. 6185, cart. 763), Letter from the Count of

Figure 5. Chestnut forest stands bound visible thanks to phenological phase. View from the Gýmeš ruin.

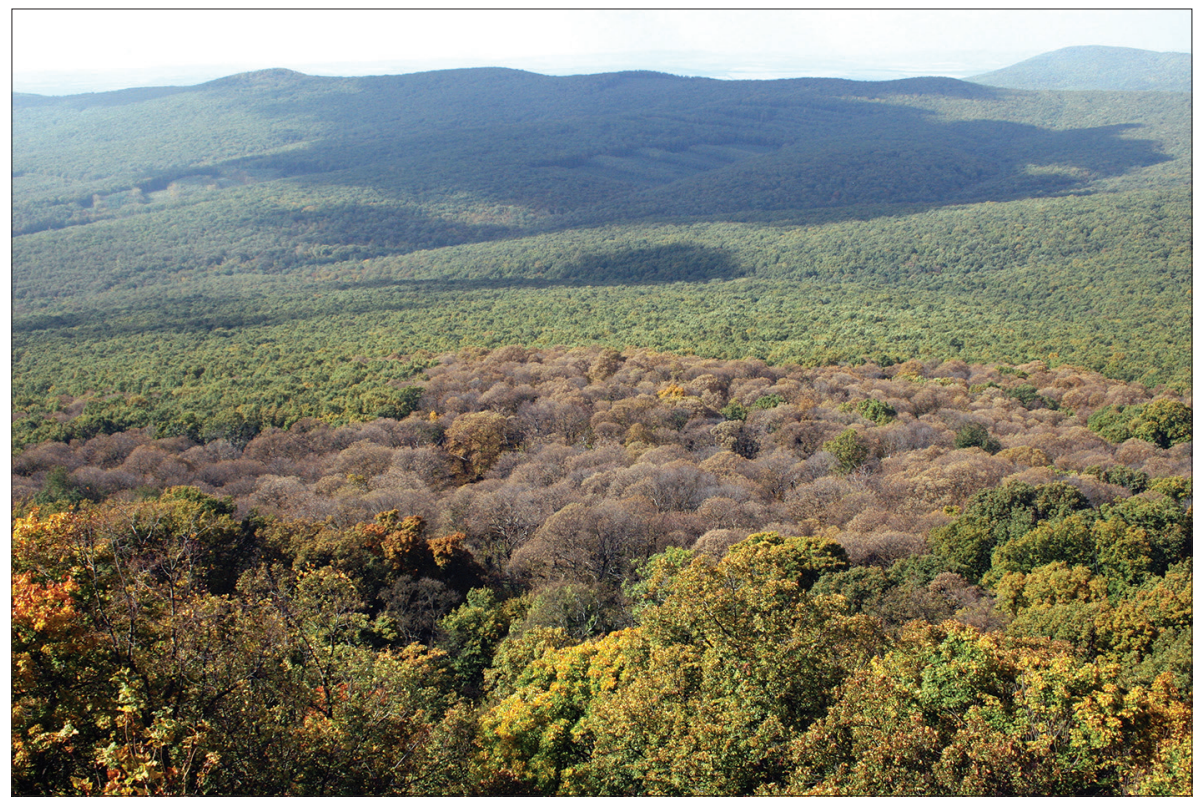


by the Jaroměřice castle kitchen inventory from 1752, where a special utensil for chestnut preparation is listed ${ }^{3}$.

\subsection{An ethnobotanical overview of Castanea sativa in the Czech Republic and a summary of its utilization in Europe}

The chestnut orchard Nasavrky in the Czech Republic and two Slovak localities, the forest stand Jelenecká under the Gýmeš ruin and Modrý Kameň were visited as part of the ethnobotanical survey. The forest stand Jelenecká under the Gýmeš ruin founded in $1240-41$ is the only locality in Slovakia whose natural dispersal ability played a key role

Questenberk to Governor Stampa dated $4^{\text {th }}$ February 1728 , stored in the Moravian Provincial Archives Brno, Kounic's Family archive, inv. n. 6185, cart. 763).

${ }^{3}$ Inventory in the Moravian Provincial Archives Brno, Kounic's Family archive, inv. n. 6126, cart. 737 in the present-day distribution (Tarinová 2009; Králík, Hřib 1979); (Figure 5). It was declared a natural reservation in 1952 (Juhásová 2010; Hrubý 1953). At present it is a 3.5 ha area and the oldest specimens are approximately 300-350 years old. The largest area with chestnuts in Slovakia is in Modrý Kameň (Juhásová 2012) (Figure 6). The present-day area is approximately 130 ha (Bolvanský et al. 2008), with the oldest specimens reaching the age of approximately 300 years. Many of the trees still derive from the original introduction (Bolvanský, Tarinová 2009). The chestnut orchard was established in the $16^{\text {th }}$ to the beginning of the $17^{\text {th }}$ centuries (Benčat' 1960).

Despite the fact that the historical sources and literature state chestnuts only as fruit along with common food stuffs, an ethnobotany survey reveals interesting and multipurpose processing. Ethnobotanical treatment of chestnuts in Slovakia and the Czech Republic is almost the same as production

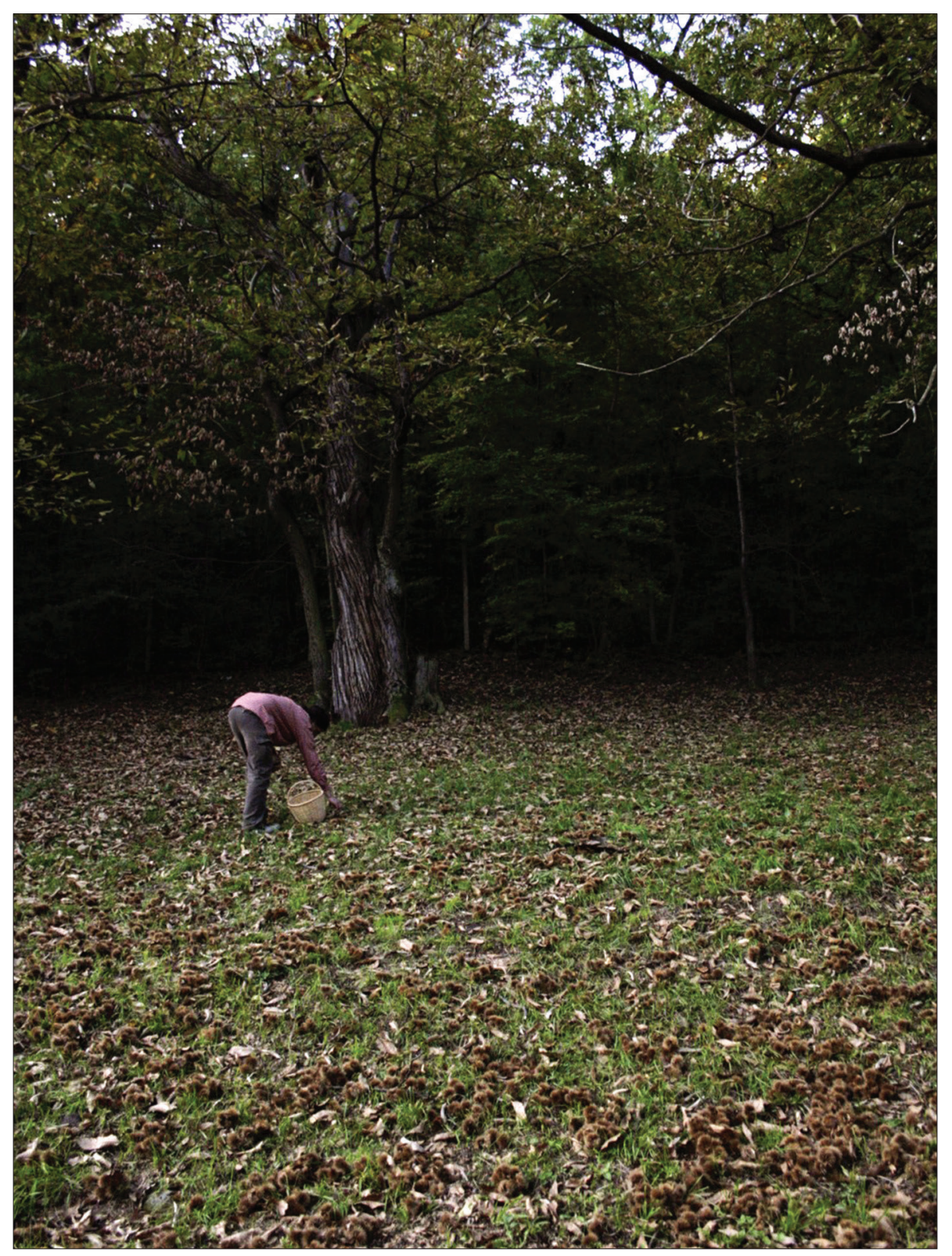

Figure 6. The orchard in Modrý Kameň located on a steep slope. During the harvest time the grass turned to the thorny brown carpet of ripe fruits. 
of sweets, stuffing poultry for feast dishes, various cakes or pancakes, purées and roast nuts of course. Moreover, the chestnut festivities take place in Modrý Kameň (Slovakia) yearly with a cultural program and numerous competitions such as the making of the best chestnut dessert, etc. This is an example of a living tradition connected with the chestnut harvest. In comparison with the poor knowledge of chestnut preparation in the chestnut regions it unfortunately seems that people only know chestnut as a seasonal fruit available in stores or roasted chestnut with hot wine or mead in the market place during the winter time. Despite the beneficial, useful and tasty various preparations of chestnuts, it can be viewed as an underestimated fruit still waiting rediscovery not only in Czech and Slovak cuisine but also as a useful tree.

Chestnuts in general are a multipurpose trees valued for their edible fruit, good quality timber, tannins, as well as the forestry landscape. Below, a review of the possible uses that are known today, and that may have been usual in past times even in the archaeological contexts here reported. Undoubtedly the primary desire for the chestnut product is specifically the quality timber valued for qualities such as moderate shrinking and high natural durability. Although it is porous, it is extremely durable in contact with soil, and also not that easy to dry. It is therefore well suited not only for furniture, building construction, tools, poles, fuel wood, etc. but also for fences, boats, electrical posts, railway ties and beams (Bounous, Marinoni 2005; Feio 2005; PereiraLorenzo, Ramos-Cabrer 2004). The broad range of uses offers the possibility of coppicing practice, primarily for fuel, tinder, construction, animal fodder, wattle fences and walls, wickerwork (Figure 7), thatching and insulation materials (Turner 2009). Coppiced poles which are thanks to tannins resistant to mould are used as supports for growing hops, pole beans and grapes. It is no coincidence that the historical presence of Castanea is in vineyard regions such as in France, Germany, Slovakia and Hungary (Hofman 1952, 40). This property has also been used for wine barrels with the addition of wood chips directly to the wine. The leaching of these tannins from the wood provides the characteristic sensorial properties in matured wines and brandies (Canas et al. 1999; Simón et al. 2009). Additional interest came from landscape and wood management such as growing attention concerning its exploitation for supplying energy wood in the form of chips and pellets (Pereira-Lorenzo et al. 2010).

Although chestnuts were assessed as food for the poor, the large cultivated chestnuts were luxury items (Davidson 2002). Nuts are balanced and quality food thanks to their nutritional composition with a low fat content, completely free of cholesterol, with low sodium and high potassium content, and moderate but high quality protein content (Bounous 2000). It was a staple food in marginal or mountainous South European regions and human survival in certain countries was due to chestnuts, with this relationship known as "chestnut civilization." Chestnuts were the basic food, the timber was used for several purposes (furniture, building construction, poles, fuel wood) and the foliage first

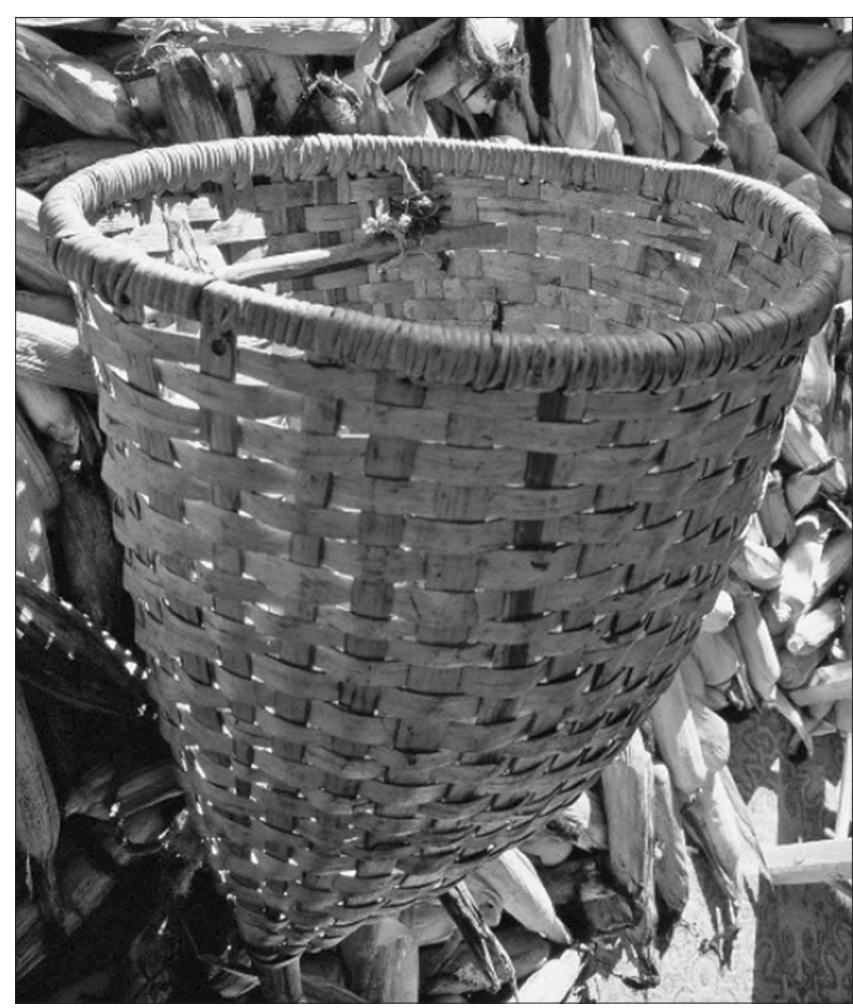

Figure 7. Basket of strips of Castanea, coppiced from living trees in Turkey. Photograph by F. Ertug (2009).

used for livestock bedding and then as a fertilizer (Bounous et al. 2005).

Although chestnut consumption in various styles is indisputable, there are no any recipes except one from the $12^{\text {th }}$ century recorded by Hildegard von Bingen (1098-1179). This German abbess and physician recommended chestnut puree for stomach ache. The recipe runs as follows: 3-5 chestnuts, 3 spoons of spelt flour, 1.5 spoons of liquorice and 1 spoon of polypody powder. Additional records are from modern times and refer to chestnut as a fruit.

It should be pointed out that the oak tree (Quercus sp.), a close botanical relative to the chestnut, and acorns are also nutritionally comparable to the cereal food supply (Š́lková et al. 2011). Both species have similar ecological requirements, moreover, chestnut tolerates higher shade (Hejný, Slavík 2003), and played a significant role in human history. As table 3 shows the dietetic compound is almost identical. A more significant variance is only in the higher carbohydrates and potassium value in chestnuts. Because of the relatively high presence of tannin, which gives acorns a bitter taste, Castanea sativa remains a more palatable crop. Peeled chestnuts did not contain condensed tannins. Tannins are in the highest content in the red internal seed shell, the brown seed shell, which you remove during food preparation, and in the new bark (Živković et al. 2009). The nuts have an outstanding potential for diverse high-quality food products: as a vegetable, as bread and pastries, as a dessert and as a snack. Semi-processed or finished products 
Table 3. Nutrient comparison between chestnuts and acorns according to: National Nutrient Database for Standard Reference Release 26, Agricultural Research Service United States Department of Agriculture (online). Available on link: http://ndb.nal.usda.gov/ndb/search/

\begin{tabular}{|c|c|c|c|c|c|}
\hline \multicolumn{3}{|c|}{ European chestnuts (dried, peeled) } & \multicolumn{3}{|c|}{ Aacorns (dried) } \\
\hline Nutrient & Unit & Value per $100 \mathrm{~g}$ & Nutrient & Unit & Value per $100 \mathrm{~g}$ \\
\hline Proximates & & & Proximates & & \\
\hline Water & $\mathrm{g}$ & 9.00 & Water & $\mathrm{g}$ & 5.6 \\
\hline Energy & kcal & 369 & Energy & kcal & 509 \\
\hline Protein & $\mathrm{g}$ & 5.1 & Protein & $\mathrm{g}$ & 8.10 \\
\hline Total lipid (fat) & $\mathrm{g}$ & 3.91 & Total lipid (fat) & $\mathrm{g}$ & 31.41 \\
\hline Carbohydrate, by difference & $\mathrm{g}$ & 78.43 & Carbohydrate, by difference & $\mathrm{g}$ & 53.66 \\
\hline Minerals & & & Minerals & & \\
\hline Calcium, $\mathrm{Ca}$ & $\mathrm{mg}$ & 64 & Calcium, $\mathrm{Ca}$ & $\mathrm{mg}$ & 54 \\
\hline Iron, $\mathrm{Fe}$ & $\mathrm{mg}$ & 2.39 & Iron, $\mathrm{Fe}$ & $\mathrm{mg}$ & 1.4 \\
\hline Magnesium, Mg & $\mathrm{mg}$ & 74 & Magnesium, Mg & $\mathrm{mg}$ & 82 \\
\hline Phosphorus, $\mathrm{P}$ & $\mathrm{mg}$ & 137 & Phosphorus, P & $\mathrm{mg}$ & 103 \\
\hline Potassium, K & $\mathrm{mg}$ & 991 & Potassium, K & $\mathrm{mg}$ & 709 \\
\hline Sodium, $\mathrm{Na}$ & $\mathrm{mg}$ & 37 & Sodium, $\mathrm{Na}$ & $\mathrm{mg}$ & 0 \\
\hline Zinc, $\mathrm{Zn}$ & $\mathrm{mg}$ & 0.35 & Zinc, $\mathrm{Zn}$ & $\mathrm{mg}$ & 0.67 \\
\hline Vitamins & & & Vitamins & & \\
\hline Vitamin C, total ascorbic acid & $\mathrm{mg}$ & 15.1 & Vitamin $\mathrm{C}$, total ascorbic acid & $\mathrm{mg}$ & 0.0 \\
\hline Thiamin & $\mathrm{mg}$ & 0.354 & Thiamin & $\mathrm{mg}$ & 0.149 \\
\hline Riboflavin & $\mathrm{mg}$ & 0.054 & Riboflavin & $\mathrm{mg}$ & 0.154 \\
\hline Niacin & $\mathrm{mg}$ & 0.854 & Niacin & $\mathrm{mg}$ & 2.406 \\
\hline Vitamin B-6 & $\mathrm{mg}$ & 0.666 & Vitamin B-6 & $\mathrm{mg}$ & 0.695 \\
\hline Folate, DFE & $\mu \mathrm{g}$ & 110 & Folate, DFE & $\mu g$ & 115 \\
\hline Vitamin B-12 & $\mu g$ & 0.00 & Vitamin B-12 & $\mu \mathrm{g}$ & 0.00 \\
\hline Vitamin A, RAE & $\mu g$ & 0 & Vitamin A, RAE & $\mu g$ & 0 \\
\hline Vitamin A, IU & IU & 0 & Vitamin A, IU & IU & 0 \\
\hline Vitamin D (D2 + D3) & $\mu g$ & 0.0 & & & \\
\hline$\underline{\text { Vitamin D }}$ & IU & 0 & & & \\
\hline Lipids & & & Lipids & & \\
\hline Fatty acids, total saturated & $\mathrm{g}$ & 0.736 & Fatty acids, total saturated & $\mathrm{g}$ & 4.084 \\
\hline Fatty acids, total monounsaturated & $\mathrm{g}$ & 1.349 & Fatty acids, total monounsaturated & $\mathrm{g}$ & 19.896 \\
\hline Fatty acids, total polyunsaturated & $\mathrm{g}$ & 1.546 & Fatty acids, total polyunsaturated & $\mathrm{g}$ & 6.052 \\
\hline Cholesterol & $\mathrm{mg}$ & 0 & Cholesterol & $\mathrm{mg}$ & 0 \\
\hline
\end{tabular}

include dried chestnuts, flour, creams, peeled and frozen nuts, flakes, and beer or liquor (Bounous, Marinoni 2005). In France, Italy, Switzerland and Spain the most appreciated transformed chestnut fruit are the 'marrons glacées' when nuts are submerged in a sugar-rich solution and then covered with glucose. They are consequently cooked in an oven to crystallize the sugar and the luxurious candy is ready (Bergougnoux 1978, 99; Davidson 2002).

The chestnut market at present reflects the changing needs of a society requiring organic food and environmentally friendly products from local areas (Conedera, Krebs 2008). Chestnuts have become increasingly important with respect to human health, for example, as an alternative glutenfree flour source (de Vasconcelos et al. 2007) while other various chemical compounds find medicinal purposes for it (de Vasconcelos et al. 2010). Phenolic compounds and condensed tannins in Castanea sativa can be a potential resource of natural tannins with possible application in a diet in the prevention of certain diseases, such as cardiovascular disease (Živković et al. 2009). As a medicinal herb and roasted with salt and pepper, chestnuts are even mentioned as an aphrodisiac in the Matthioli herbarium (Matthioli 1596).

\section{Conclusion}

Castanea sativa is an essential tree associated with human activity. Not only the huge dimension of its growth but its various utilizations make the chestnut in particular one of the most important cultural plants in history. Its presence in archaeobotanical collections is nevertheless sporadic. The reason for the rare findings of chestnuts remains uncertain. It may suggest the burning of the shells related to the preparation process or their being fed to domestic animals. Even the lack of Early Modern period studies in the Czech Republic as well as elsewhere can be proposed. Numerous findings of chestnut macro remains in waste vault infills placed Prague Castle among the most significant 
archaeobotanical localities. The actual preparation and manner of how chestnuts have been consumed in the Early Modern Period in Prague can only be assumed. There are not any recipes or instructions apart from chestnut classification as a fruit. A conclusion can be reached that the presence of chestnut as an ordinary commodity symbolizes the high socioeconomic status of Prague Castle.

\section{Acknowledgements}

This work was supported by the Student Grant Agency from the Faculty of Science, University of South Bohemia in 2010 (SGA2010/008). It was also supported by the project "PAPAVER - Centre for human and plant studies in Europe and Northern Africa in the postglacial period", reg. No. CZ.1.07/2.3.00/20.0289 and co-financed by the European Social Fund and the state budget of the Czech Republic. Many thanks belong to my colleagues and the authors for their papers and kind communication. I would also like to thank Rostislav Smíšek who provided the archive material and Pavla Loucká for the etymological information.

\section{References}

ALSLEBEN, A. 2007: Food consumption in the Hanseatic towns in Germany. In: Karg, S. (Ed.): Medieval food traditions in Northern Europe. Studies in Archaeology and History 12, Copenhagen: National Museum of Denmark, 13-31.

ANAGNOSTAKIS, S. L. 2009: Identification of Chestnut Trees. The nutshell, 11-22.

BAXA, P., ČEJKA, T., HAJNALOVÁ, M., PIŠÚT, P., ŠEFČÁKOVÁ, A. 2003: Dunajské ramená v historickom jadre Bratislavy. In: Hašek, V., Nekuda, R., Unger, J. (Eds.): Ve službách archeologie 4, Brno, 135-146.

BENČǍ̆, F., 1960: Rozširenie gaštana jedlého (Castanea sativa Mill.) a jeho stanovištné podmienky na Slovensku. Slovenská akadémia vied, Bratislava.

BENECKE, N., DONAT, P., GRINGMUTH-DALLMER, E., WILLERDING, U. 2003: Frühgeschichte der Landwirtschaft in Deutschland. Beiträge zu Ur- und Frühgeschichtliche Mitteleuropa 14. Langenweißbach.

BENEŠ, J., ČULÍKOVÁ, V., KOSŇOVSKÁ, J., FROLÍK, J., MATIÁŠEK, J. 2012: New plants at Prague Castle and Hradčany in the Early Modern Period: a History of selected species, Interdisciplinaria Archaeologica - Natural Sciences in Archaeology III/1/2012, 103-114.

BERGOUGNOUX, F. 1978: Conservation, transformation et utilisation des châtaignes et marrons. Institut National de Vulgarisation pour les Fruits, Légumes et Champignons.

BOLVANSKÝ, M., TARINOVÁ, D. 2009: Following Chestnut Footprints (Castanea spp.) Cultivation and Culture, Folkrore and History, Traditions and Uses, Scripta Horticolturae 9, 122-127.

BOLVANSKÝ, M., BRINDZA, J., TÓTH, D., BACIGÁLOVÁ, K., FERIANC, P., KARELOVÁ, E., HARICHOVÁ, J., KAČÁNIOVÁ, M., HORČIN, V., MENDEL, L., UŽÍK, M., 2008: Gaštan jedlý (Castanea sativa Mill.). SPU v Nitre, Nitra.

BUONINCONTRI, M. P., DI FALCO, G., MOSER, D., DONNINI, D., DI PASQUALE, G. 2006: Il castello di Miranduolo (Siena): dati archeobotanici per il X-XI secolo. (Workshop Archeobotanica e alimentazione). Atti Soc. Nat. Mat. Modena 137, 355-372.

BOUNOUS, G., BOTTA, R., BECCARO, G. 2000: The chestnut: the ultimate energy source. Nutritional value and alimentary benefits. Nucis - Information Bulletin of the Research Network on Nuts (FAO-CIHEAM) 9: 44-50.
BOUNOUS, G., MARINONI, D. T. 2005: Chestnut: Botany, Horticulture, and Utilization. Horticultural Reviews 31, 291-347.

CANAS, S., LEANDRO, M. C., SPRANGER, M. I., BELCHIOR, A. P. 1999: Low molecular weight organic compounds of chestnut wood (Castanea sativa L.) and corresponding aged brandies. Journal of Agricultural and Food Chemistry 47, 5023-5030.

CASTElletTI, L., CASTIGLIONI, E. 1991: Resti vegetali. In: BROGiOlO, G. P., CASTElletTI, L. (Eds.): Archeologia a Monte Barro I, Il grande edificio e le torri. Editrice Stefanoni, Lecco.

CASTIGLIONI, E., COTTINI, M., ROTTOLI, M. 2001: I resti archeobotanici. In: BROGIOLO, G. P., CASTELLETTI, L. (Eds.) 2001: Archeologia a Monte Barro, II - Gli scavi 1990-97 e le ricerche al S. Martino di Lecco, Consorzio Parco Monte Barro. Museo Archeologico "P. Giovio" Como, Lecco. 223-247.

CONEDERA, M., KREBS, P. 2008: History, present situation and perspective of chestnut cultivation in Europe. Acta Horticulturae (ISHS) 784, 23-28.

CONEDERA, M., KREBS, P., TINNER, W., PRADELlA, M., TORRIANI, D. 2004: The cultivation of Castanea sativa (Mill.) in Europe, from its origin to its diffusion on a continental scale. Vegetation History and Archaeobotany 13, 161-179.

COTTON, C. M. 1996: Ethnobotany: principles and applications. John Wiley \& Sons, Chichester, UK.

ČÍŽEK, K. 1994: Křišt’an z Prachatic a jeho dílo z hlediska botaniky. Sborník Západočeského muzea v Plzni, Přiroda 90, 1-39.

DAVIDSON, A. 2002: The Penguin Companion to Food. Penguin Books Ltd., London.

FEIO, A. 2005: Inspection and Diagnosis of Historical Timber Structures: NDT Correlations and Structural Behaviour. MS. PhD thesis. Deposited: University of Minho.

GABRIELLI, A. 1994: La civilta' del castagno. Monti e boschi 65, 3.

GYULAI, F. 2010: Archaeobotany in Hungary: Seed, Fruit, Food and Beverage Remainsin the Carpathian Basin from the Neolithic to the Late Middle Ages. Archaeolingua, Budapest.

HALTOFOVÁ, P., JANKOVSKÝ, L. 2003: Distribution of sweet chestnut Castanea sativa Mill. in the Czech Republic. Journal of forest science 49, 2003 (6), 259-272.

HALTOFOVÁ, P., PALOVČÍKOVÁ, D., JANKOVSKÝ, L. 2005: Distribution and Health Condition of Sweet Chestnut (Castanea sativa Mill.) in the Czech Republic. Acta horticulturae 693, 159-164.

HEJNÝ, S., SLAVÍK, B. (Eds.) 2003: KVĚTENA ČR, dil 2. Academia, Praha, 20-21.

HOFMAN, J. 1952: Pěstováni kaštanu jedlého a škumpy jako dřevin tř́slovinných. Nakladatelství Brázda, Praha.

HRDLIČKA, J. 2000: Hodovní stůl a dvorská společnost: Strava na raně novověkých aristokratických dvorech v českých zemich (1550-1650). Historický Ústav Jihočeské Univerzity, České Budějovice.

HRUBÝ, K. 1953: Kaštanový prales u Gýmeše. ŽIVA 4, 135-136.

JANKOVSKÁ, V.: Address: Department of Vegetation Ecology, Institute of Botany, Academy of Sciences of the Czech Republic, Poříčí, Brno, announced on $23^{\text {th }}$ November 2011.

JUHÁSOVÁ, G., ADAMČÍKOVÁ, K., KOBZA, M., ONDRUŠKOVÁ, E., BARIAK, A., PLEVO, Š. 2010: HUSK: „In 24th hour" Programme for saving of European chestnuts (Chestnutsave Project code: HUSK/0801/2.2.1/0187), Hungarian-Slovak Co-operation in 2007-2013. Ústav ekológie lesa SAV Zvolen, Pobočka biológie drevín Nitra, Mestský úrad Modrý Kameň, Zvolen - Modrý Kameň.

JUHÁSOVÁ, G., ADAMČÍKOVÁ, K., KOBZA, M, ONDRUŠKOVÁ, E. 2012: Population structure of Cryphonectria parasitica in the Modrý Kameň region. Journal of Plant Protection Research 52, 1, 24-27.

JUNGMANN, J. 1836: Slownjk česko-německý, díl II. Praha.

KAMENICKÁ, E. 1990: Analysis of well infill located in Jesuits church and Korálkovský house basement. Final report. Výzkumy v Čechách.

KAMENICKÁ, E.: Address: National Heritage Institute, Prešovská 7, Plzeň, announced on $16^{\text {th }}$ November 2012.

KOBLÍŽEK, J. 2006: Jehličnaté a listnaté dřeviny našich zahrad a parků. Sursum, Praha.

KOČÁR, P., JANKOVSKÁ, V., STAREC, P., HUML, V. 2007 : Paleoethnobotanical Analysis of Modern Age Anthropogenic Sediment from Prague, Melantrichova street 465-I. Ve službách archeologie 2, 
26-37.

KOČÁR, P., KOČÁROVÁ, R., SƯVOVÁ, Z., PETR, L. 2009: The Early Modern period cesspit at the Capuchin Monastery on the site of Prague's Republic Square from the perspective of environmental archaeology. Studies in Post-Mediaval Archaeology 3, 391-406.

KOKEŠ, O. 1950: České kaštanky. Ochrana př́rody 5, 104-109.

KOKEŠ, O. 1958: O původu našich kaštanek. ŽIVA 4, 132-133.

KOS, J. MARŠÁKOVÁ, M. 1997: Chráněná území České republiky. The Agency for Nature Conservation and Landscape Protection of the Czech Republic, Praha.

KOTT, F. Š. 1878: Česko-německý slovnik zvláště grammatickofraseologický, díl I. Praha.

KRÁLÍK, J, HŘIB, J. 1979: Kaštan jedlý u nás. ŽIVA 1, 16.

LAUTERI, M., PLIURA, A., MONTEVERDI, M. C., BRUGNOLI, E., VILLANI, F., ERIKSSON, G. 2004: Genetic variation in carbon isotope discrimination in six European populations of Castanea sativa Mill. originating from contrasting localities. Journal of Evolutionary Biology, 17: 1286-1296.

LEPETZ, S., MATTERNE, V., RUAS, M. P., YVINEC, J. H. 2002: Culture et élévage en France septentrionale de l'âge du Fer à l'an Mil. In: BELMONT, A. (Ed.): Autour d'Olivier de Serres. Pratiques agricoles et pensées agronomique du Neolithique aux enjeux actuels. Actes du Colloque du Pradel (27-29 septembre 2000). Bibl Hist Rurale 6. Caen, 77-108.

MARINVAL, P. 2004: Offrandes alimentaires d'origine végétale en contexte funéraire gallo-romain. In: Baray, L. (Ed.): Archéologie des pratiques funéraires. Approches critiques. Actes de la table ronde de BIBRACTE, 7-9 juin 2001, 197-206.

MATTHIOLI, P. O. 1596: Herbář neboli bylinár̆ I-III. Praha 2005.

MAZZANTI, M. B., BOSI, G., MERCURI, A. M., ACCORSI, C. A.,GUARNIERI, CH. 2005: Plant use in a city in Northern Italy during the late Mediaeval and Renaissance periods: results of the archaeobotanical investigation of "The Mirror Pit" $\left(14^{\text {th }}-15^{\text {th }}\right.$ century A.D.) in Ferrara. Vegetation history and archaeobotany 14, 142-145.

MAZZANTI, M. B., BOSI, G., GUARNIERI, CH. 2009: The useful plants of the city of Ferrara (Late Medieval/Renaissance) based on archaeobotanical records from middens and historical/culinary/ethnobotanical documentation. In: Morel, J.-P., Mercuri, A. M. (Eds.): Plant and Culture: seeds of the cultural heritage of Europe. Edipuglia, 93-106.

MERCURI, A. M., BANDINI MAZZANTI, M., FLORENZANO, A., MONTECCHI, M. C., RATTIGHIERI, E. 2013: Olea, Juglans and Castanea: The OJC group as pollen evidence of the development of human-induced environments in the Italian peninsula. Quaternary International, 303, 24-42.

MURPHY, P. 2003: Plant macrofossils. In: Germany, M. (Ed.): Excavations at Great Holts Farm, Boreham, Essex, 1992-94. East Anglian Archaeology 105, Chelmsford, 204-213.

NISBET, R. 2000: Alcuni aspetti di storia naturale del castagno. In: Comba, R., Naso, I. (Eds.): Uomini boschi castagne, Incontri nella storia del Piemonte. Cuneo - Rocca de' Baldi, 9-19.

NOŽIČKA, J. 1953: Proč byly na Lovosicku vysazovány jedlé kaštany. Lesnická práce 2, 68-71.

PACÁKOVÁ-HOŠŤÁLKOVÁ, B., PETRŮ, J., RIEDL, D., SVOBODA, A. M. 2004: Zahrady a parky v Čechách, na Moravě a ve Slezku. Libri, Praha.

PASQUAle, G., AlleVATO, E., ERMOlli, E. R., COUBRAY, S., LUBRITTO, C., MARZAIOLI, F., YONEDA, M., TAKEUCHI, K., KANO, Y., MATSUYAMA, S., SIMONE, G. F. 2010: Reworking the idea of chestnut (Castanea sativa Mill.) cultivation in Roman times: New data from ancient Campania. Plant Biosystems 144/4, 865-873.

PEREIRA-LORENZO, S., RAMOS-CABRER, A. M. 2004: Chestnut, an Ancient Crop with Future. In: Production Practices and Quality Assessment of Food Crops, Vol 1, Preharvest Practice. Springer Netherlands, 105-161.

PEREIRA-LORENZO, S., MAURER, W., BOUFFIER, V., SEGATZ, E. 2010: Sustainable Orchards/Chestnut Forests Management". In: Proceedings of the Workshop Chestnut (Castanea sativa): a multipurpose European tree - Brussels 30 Sept - 01 Oct 2010. Regione Toscana, D \& V Ltd. (Georgia), 26-32.

PYŠEK, P., SÁDLO, J., MANDÁK, B. 2002: Catalogue of alien plants of the Czech Republic. Preslia 74, 97-186.
RÖSCH, M. 2002: Nüsse. In: Beck, H., Geuenich, D., Steuer, H. (Eds.): Reallexikon der Germanischen Altertumskunde 21: 548-450.

SIMÓN, B. F., ESTERUELAS, E., MUÑOZ, A. M., CADAHÍA, E., SANZ, M. 2009: Volatile compounds in acacia, chestnut, cherry, ash, and oak woods, with a view to their use in cooperage. Journal of Agricultural and Food Chemistry 57, 3217-3227.

SÝKOROVÁ, L. 2010: Klatovy. Nakladatelství Lidové noviny, Praha.

ŠÁLKOVÁ, T., DIVIŠOVÁ, M., KADOCHOVÁ, Š., BENEŠS, J., DELAWSKÁ, K., KADLČKOVÁ, E., NĚMEČKOVÁ, L., POKORNÁ, K., VOSKA, V., ŽEMLIČKOVÁ, A. 2011: Acorns as a Food Resource. An Experiment with Acorn Preparation and Taste. Interdisciplinaria Archaeologica - Natural Sciences in Archaeology II/2/2011, 139-147.

ŠOŠTARIĆ, R., KÜSTER, H. 2001: Roman Plant Remains from Veli Brijun (Island of Brioni), Croatia. Vegetation History and Archaeobotany 10, 227-233.

SVOBODA, A. M. 1978: Pěstováni kaštanovníku jedlého (Castanea sativa MILL.) v Čechách a na Moravě. Folia dendrologica 4, 23-48.

TEGTMEIER, U. 2002: Hölzer aus der Stadtkerngrabung in Duisburg. Archäologische und botanische Untersuchungen. Archaeo-Physika 14. Mainz.

TARINOVÁ, D. 2009: Jelenecká gaštanica potrebuje pomoc. Enviromagazín - Odborno-náučný časopis o životnom prostredí 6. Ministerstvo životného prostredia Slovenskej republiky a Slovenská agentúra životného prostredia, Banská Bystrica.

URBISZ A., URBISZ A. 2007: European chestnut (Castanea sativa Mill.) a tree naturalized on the Baltic Sea coast? Polish Journal of Ecology 55, $1,175-179$.

DE VASCONCELOS, M. C. B. M., BENNETT, R. N., ROSA, E. A. S., FERREIRA-CARDOSO, J. V. 2007: Primary and secondary metabolite composition of kernels from three cultivars of Portuguese chestnut (Castanea sativa Mill.) at different stages of industrial transformation. Journal of Agricultural and Food Chemistry, 3508-3516.

DE VASCONCELOS, M. C. B. M., BENNETT, R. N., ROSA, E. A. S., FERREIRA-CARDOSO, J. V. 2010: Composition of European chestnut (Castanea sativa Mill.) and association with health effects: fresh and processed products. Journal of Agricultural and Food Chemistry, 15781589.

VĚTVIČKA, V. 1999: Evropské stromy, Aventinum, Praha.

VONDRÁČKOVÁ, K. 1996: Nálezy ze středověkých studní pod jezuitským kostelem v Klatovech. Sborník Západočeského muzea v Plzni, Historie XIII, 134-159.

WIETHOLD, J. 2003: How to trace "Romanisation" of central Gaule by archaeobotanical analysis? - Some considerationes on new archaeobotanical results from France Centre-Est. In: Actualité de la Recherche en Histoire et Archéologie agriares, Actes du colloque international AGER V, septembre 2000. Besançon, 269-282.

WINTER, Z. 1892: Kuchyně a stůl našich předků: Ličeni dějepisné ze století XVI. Bačkovský, Praha.

WINTER, Z. 1906: Dějiny řemesel a obchodu v Čechách v 14. a v 15. století. Česká akademie císaře Františka Josefa pro vědy, slovesnost a umění, Praha.

ZACH, B. 2002: Vegetable offerings on the Roman sacrificial site in Mainz, Germany - short report on the first results. Vegetation History and Archaeobotany 11, 101-106.

VAN ZEIST, W., BOTTEMA, S. 1991: Late Quaternary Vegetation of the Near East. L. Reichert, Wiesbaden.

ŽIVKOVIĆ, J., MUJIĆ, I., ZEKOVIĆ, Z., NIKOLIĆ, G., VIDOVIĆ, S., MUJIĆ, A. 2009: Extraction and Analysis of Condensed Tannins in Castanea sativa Mill. Journal of Central European Agriculture 10/3, 283-288.

\section{Online sources}

Online Etymological Dictionary (C) 2001-2013 Douglas Harper: http:// www.etymonline.com/index.php?search=castanea + crenata

Patrologia Latina, p. 1227 B, Medical records collection by Hildegard von Bingen (1098-1179), published in 1855. http://www.myschwerk. webzdarma.cz/mainpage.html

Online map of Castanea sativa distribution in the Czech Republic, Haltofová, P., Jankovský, L., Lička D., ÚOLM LDF MZLU v Brně, (C) $2001-2005$ : http://thuja.mendelu.cz/kastanovnik/index $2 . \mathrm{htm}$ 